\title{
Determination of milk production losses in Valle del Belice sheep following experimental infection of Mycoplasma agalactiae
}

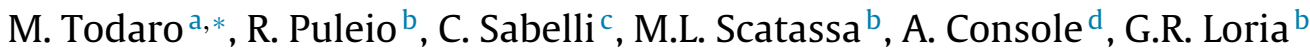 \\ a Dipartimento Scienze Agrarie e Forestali, Università di Palermo, Italy \\ ${ }^{b}$ Istituto Zooprofilattico Sperimentale della Sicilia, Palermo, Italy \\ c IZO Research and Development Department, Brescia, Italy \\ ${ }^{d}$ Istituto Sperimentale Zootecnico per la Sicilia, Palermo, Italy
}

\section{A R T I C L E I N F O}

\section{Article history:}

Received 27 June 2014

Received in revised form 7 October 2014

Accepted 9 October 2014

Available online 18 October 2014

\section{Keywords:}

Contagious agalactia

Milk losses

Milk composition

\begin{abstract}
A B S T R A C T
Economic losses due to contagious agalactia (CA) in small ruminant herds are mainly associated with significant reductions in or complete loss of dairy production, mortality, abortions, ill thrift, early culling and costs of control. With the aim of estimating milk production losses caused by CA, 46 primiparous lactating Valle del Belice ewes were monitored after experimental infection. Sixty days after lambing, two ewes were each experimentally infected with a single dose of $10^{8} \mathrm{CFU} / \mathrm{ml}$ of a live Mycoplasma agalactiae strain in both teats by intracanalicular route. Three days after inoculation, the infection was spread manually by the milkers dipping their hands in the pooled milk from the experimentally infected ewes just before milking each of the uninfected sheep. The milk yield was recorded daily (morning and evening) for 12 weeks: 5 weeks before and 7 weeks after infection. Daily milk data, collected from each ewe, were used to design individual lactation curves in order to estimate the impact of CA infection. Individual milk samples were screened for the presence of $M$. agalactiae as well other pathogens which cause mastitis in small ruminants comprising Staphylococcus aureus, coagulase negative-staphylococci (CNS), Corynebacterium spp. and Streptococcus spp. No pathogens were detected in the milk of 10 (22\%) of the 46 ewes kept with the experimentally infected sheep. There was a reduction of $17 \%$ in milk output of $19(41 \%)$ ewes from which M. agalactiae was isolated; the 17 (37\%) remaining ewes had a similar drop in milk production but recovered quickly within 2-3 weeks, so the final losses were estimated to be $3 \%$. The infected milk showed a significantly higher somatic cell count when mycoplasma excretion in milk was $>10^{3} \mathrm{CFU} / \mathrm{ml}$. Percentages of milk protein and casein were higher in milk excreting $M$. agalactiae due to concentration, in contrast the percentage of lactose in the milk was significantly lower. No significant effect of M. agalactiae was found on the percentage of milk fat.

In conclusion, the loss of milk following CA infection is variable and probably related to the degree of exposure and capacity of the individual ewe to resist the pathogen.
\end{abstract}

(c) 2014 Elsevier B.V. All rights reserved.
* Corresponding author at: Dipartimento di Scienze Agrarie e Forestali, Università degli Studi di Palermo, viale delle Scienze, 13, 90128 Palermo, Italy. Tel.: +39091 23896061; fax: +390916515531.

E-mail address: massimo.todaro@unipa.it (M. Todaro).

\section{Introduction}

In sheep and goats, mycoplasma infections often result in pneumonia, eye disease, arthritis and septicaemia. Some mycoplasma infections such as contagious agalactia (CA), which was first described 170 years ago, are associated with mastitis particularly in countries surrounding 
the Mediterranean Sea. In domestic small ruminants, economic losses are mainly associated with a partial or complete loss of milk production, abortions in adults, limited growth, early culling of the young and mortality in acute outbreaks (Ramirez et al., 2001). On top of these should be added the high costs of treatment and control.

Estimating the economic impact of CA is a complex issue, probably because it is connected with traditional husbandry typical of Mediterranean areas; invariably, however, it has a strong impact on the local economy because of its high morbidity rate which is why it is often known as "the shepherd's nightmare" (Nicholas and Loria, 2014). Moreover, due to the indirect effect on the quality of milk produced, it is likely that the impact of CA is underestimated, especially in dairy livestock (Corrales et al., 2004; Contreras et al., 2008).

The classical CA syndrome is characterized by mastitis, keratoconjunctivitis and arthritis. The infection of the udder evolves as an interstitial mastitis which starts with a swelling, rise in temperature and pain in the affected udder following by a drastic decrease in milk production and quality (Nicholas et al., 2008). After some days, a reduction in size of one or both organs follows. Generally, the condition improves after some weeks with partial restoring of the udder's function but milk output remains low. If the infection becomes chronic, sclerosis and loss of the whole organ are seen (Marcato, 1992). Weak lambs are also seen due to mastitis and reduced milk production of their dams. Conjunctivitis and arthritis is also seen in about $5-10 \%$ of the affected flock (Guarda and Mandelli, 1989). The course of the disease generally evolves in one month but the chronic form can be observed for up to three months (Farina et al., 2002). In Italy the disease can vary from the clinically visible infection, typical of farms which have never previously been exposed, to the subclinical syndrome more often reported in endemic areas. There are many factors influencing the severity of the disease and related losses: pastoralism, susceptible dairy breeds, prolonged lactation, quality and quantity of pasture available, disease status of the flocks, and pathogenicity of the strains involved (Foglini, 1997).

CA has a strong socio-economic impact on traditional farming often carried out by poorer farmers and as a consequence it has been classified as an OIE listed disease (Solsona et al., 1996).

CA has never been a priority of the Italian government mainly because small ruminant livestock is less profitable compared to the more lucrative cattle industry located in north Italy. The main reason for this lack of consideration is probably related to the poor appreciation of the substantial economic losses caused by the disease. The aim of this study was to quantify the losses in milk production following an experimental infection with a pathogenic strain of Mycoplasma agalactiae in an effort to simulate losses incurred in the field.

\section{Materials and methods}

\subsection{Animals}

The experiment was carried out on $46 \times 12-15$ month-old primiparous lactating ewes of the Valle del Belice breed, and kept the Istituto Sperimentale Zootecnico per la Sicilia (ISZS) in Palermo. The ewes were selected from three farms in the region of Santa Margherita di Belice, Agrigento, (the origin area of the Valle del Belice breed) according to their presumed stage of lambing determined by sonographic diagnosis. The farms had been selected on the basis of the herd history which had no reports of CA or use of vaccination against CA. A range of diagnostic tests including commercial competitive ELISA (CIV test ${ }^{\circledR}$ ), isolation of mycoplasma and PCR on repeated bulk milks sampling carried out prior to experimental infection confirmed the CA-free status of the flocks.

The pregnant ewes were taken to the ISZS 60 days before lambing. After lambing, lambs were separated from their dams after an average of 12-18 days and were hand-milked twice daily at 7.00 a.m. and 4.00 p.m. The animals' diet was composed of $0.4 \mathrm{~kg} /$ head/day of concentrate administered during each milking, while between the two milking the ewes were fed at pasture. After the evening milking, ewes received a supplement with hay given ad libitum.

Before the experiment, the sheep were clinically monitored by veterinarians of the Istituto Zooprofilattico Sperimentale della Sicilia (IZS) in order to detect other diseases, especially those involving the mammary glands, including Staphylococcus aureus the most common pathogen of the sheep udder in Sicily. Serum samples were also tested serologically to detect any previous contacts with $M$. agalactiae. The first milk sampling was performed on $01 / 23 / 2013$ and the last on $04 / 22 / 2013$.

\subsection{Experimental infection}

On 03/04/2013 two random lactating ewes were experimentally infected by a single dose of $10^{8} \mathrm{CFU} / \mathrm{ml}$ of a live $M$. agalactiae strain into both teats by intracanalicular route (Tola et al., 1999). The strain (Bubbonia Farm strain) had been recently isolated from an outbreak of CA in Sicily and confirmed by biochemical and PCR analysis. It had been cultured in modified Hayflick's broth $\left(500 \mathrm{ml}\right.$ ) (Miles and Nicholas, 1998) for $72 \mathrm{~h}$ at $37^{\circ} \mathrm{C}$. The broth culture was centrifuged at $10,000 \mathrm{rpm}$ for $30 \mathrm{~min}$, re-suspended in the same volume of phosphate buffered saline (PBS) solution, $\mathrm{pH} 7.2$ and stored in $1.5 \mathrm{ml}$ cryovials at $-80^{\circ} \mathrm{C}$. Viable $M$. agalactiae antigen was quantified before inoculation by the method described elsewhere (Miles and Nicholas, 1998).

\subsubsection{Challenge}

In the first three days after the experimental infection, milk was collected from the experimentally infected ewes (which quickly showed signs of (A) during the two daily milking. Each milker dipped his hands in this infected milk immediately before milking each of the other ewes in the challenge and control groups. Then, in the following days, normal milking of all ewes continued. The challenge day was considered as day 0 of the experiment. This kind of challenge was chosen to closely mimic natural transmission seen in Mediterranean countries where M. agalactiae mainly occurs. The most common risk factor has been recognized as the hands of milkers which transfer the infection from sick to healthy udders (Tola et al., 1999; Agnone et al., 2013). As stated above this method better resembles natural infection and causes less stress to animals although the large amount of antigen inside the teats can cause transient discomfort.

The experiment was performed in accordance with the Code of Practice for Housing and Care of Animal used in Scientific Procedures (EU Directive 2010/63/EU) and with the authorization of the Italian Ministry of Health (DM n. 101/2006-A).

\subsection{Microbiological analysis}

Serological and clinical data of the presence or absence of mastitis, arthritis and keratoconjunctivitis were recorded weekly till the 7th week after challenge. $M$. agalactiae isolation was carried out from individual milk samples taken weekly at morning milking by standard procedures (Nicholas and Baker, 1998). The above samples were additionally cultured on $5 \%$ sheep blood agar (Merck, Darmstadt, Germany) at $37^{\circ} \mathrm{C}$ under both aerobic and anaerobic conditions, as well as on tryptic soy agar (DIFCO Laboratories, Detroit, MI, USA) in order to detect other bacterial species. Isolates were then identified using standard biochemical tests (Poveda and Nicholas, 1998) and PCR based on the 16S rRNA gene as described previously (McAuliffe et al., 2003). The determination of viable cells in milk samples was carried as previously described and the number of the colonies counted was calculated according to Meynell and Meynell (1970). Milk samples were grouped on the basis of the amount of mycoplasma detected i.e. absence, $<10^{3} \mathrm{CFU} / \mathrm{ml},>10^{3} \mathrm{CFU} / \mathrm{ml}$.

The presence of $M$. agalactiae was also confirmed by specific PCR and culturing milk samples as described elsewhere (McAuliffe et al., 2003; Poveda and Nicholas, 1998).

Milk samples, collected aseptically from each half udder weekly at morning milking were examined for other mastitis agents, the bacteriological analysis was carried out in accordance to the recommendations of the FIL-IDF (1981). A loop of the sample $(0.01 \mathrm{ml})$ was taken and inoculated onto Columbia 5\% sheep blood agar plates. The inoculated plates were incubated in anaerobic environment at $37^{\circ} \mathrm{C}$ and examined for growth after $24 \mathrm{~h}$. When nothing had grown, they were reincubated up to further $48 \mathrm{~h}$ and reexamined. Specific identification of Staphylococcus isolated was made using standardized micromethods (API Staph - BioMerieux). Isolates were considered positive in the case of $S$. aureus from one colony per inoculum, while in the case of coagulase negative staphylococci (CNS) from five or more identical colonies. Pathogens were divided into 'major' (S. aureus) and 'minor' (coagulase negative staphylococci) according to their pathogenicity (Harmon, 1994).

For other pathogens such as Enterobacteriaceae, Streptococcus spp. and Corynebacterium, we followed standard procedures using MacConkey agar, TKT medium (thallium sulfate crystal violet beta toxin) and blood agar respectively, incubated at $37^{\circ} \mathrm{C}$ with and without $5 \%$ $\mathrm{CO}_{2}$. 


\subsection{Milk data, lactation curves and statistical analysis}

After the removal of the lambs, daily milk yield was recorded weekly at the morning and evening milking. At the morning milking only, individual milk samples without preservative were taken and analyzed for somatic cell count, fat, protein, casein and lactose percentages by infrared method (Combi-foss 6000, Foss Electric, Illerød, Denmark).

A total of 12 milk samplings were carried out on each ewe during the experiment: 5 before the experimental infections and challenge and 7 thereafter.

On the basis of the microbiological results: presence of M. agalactiae, or colonies of $S$. aureus (STAU) or other minor pathogens (CNS), the 46 ewes were classified as "Healthy" or "Infected". The infected ewes reacted in a different way to mycoplasma infection and were coded on the basis of lactation curve trend as follows:

- Type 1: ewes with decreased amounts of milk.

- Type 2: ewes with decreased amount of milk but which had recovered daily milk production after 15-20 days.

- Type 3: ewes whose production performance was not affected.

The milk data collected from each healthy ewe were used to estimate the parameters of lactation curve. To estimate the pattern of the milk production a second-order polynomial $\left(y=a+b^{*} x-c^{*} x^{2}\right)$ was used, that best fitted individual milk yield respect to other mathematical models often used to define the lactation curves of dairy ewes (Wood, 1967; CappioBorlino et al., 1995, 1997). To estimate the $a, b$ and $c$ lactation curves parameters a nonlinear procedure was employed (NLIN procedure of SAS, vs 9.2). The mean lactation curve of healthy ewes was used to compare the trend of real milk yield from each group of infected ewes (Type 1,2 and 3).

Real and estimated daily milk yield were used to calculate the total milk production from January 23 to April 22 ( 89 days) according to the Fleischmann method (CICPE, 1992), and a two-way statistical model of analysis of variance (GLM procedure of SAS, vs 9.2) that took into account the interaction between the type of production (real vs estimated milk yield) and the type of reaction to M. agalactiae (Healthy, Type 1, 2 and 3) was employed.

Individual milk composition data were analyzed with the following mixed model of analysis of variance (MIXED procedure of SAS, vs 9.2):

$Y_{i j k l m}=\mu+D A T E_{i}+M_{j}+P_{1}+(M x P)_{j l}+E W E_{k}+\varepsilon_{i j k l m}$

where $Y_{i j l k m}=$ dependent variable; $\mu$ =general mean; $D A T E_{i}=$ fixed factor date of sampling ( $i: 1.7) ; M_{j}=$ fixed factor Mycoplasma detected $(j$ : negative, $\left.<10^{3} \mathrm{CFU} / \mathrm{ml},>10^{3} \mathrm{CFU} / \mathrm{ml}\right) ; P_{1}=$ fixed factor Mastitis agents ( $l$ : negative, $S$. aureus (STAU), Coagulase-negative staphylococci (CNS)); $(M \times P)_{j l}=$ fixed factor interaction between Mycoplasma detected and Mastitis agents $(j l: 1.6) ; E W E_{k}=$ random factor $(k: 1.46) ; \varepsilon_{i j l k m}=$ casual error.

Comparisons between means were tested with the Student's $t$ test.

\section{Results and discussion}

The experimental infection showed a similar disease pattern to field outbreaks with varying degrees of clinical signs. Bacteriological screening of milk samples showed 10 of 46 sheep were free of $M$. agalactiae, S. aureus and other minor pathogens (Coagulase-negative staphylococci) and did not show clinical signs of mastitis throughout the trial. The other 36 sheep were considered infected because M. agalactiae was isolated from the milk at least one or more times during the weekly collections. The frequency of isolations of Enterobacteria, Streptococci and Corynebacteria was negligible (Bergonier and Berthelot, 2003).

On the basis of the lactation curve and the degree of reaction to infection by mycoplasma, the infected ewes were classified as follows:

- Type 1: 13 ewes.

- Type 2: 17 ewes.

- Type 3: 6 ewes.

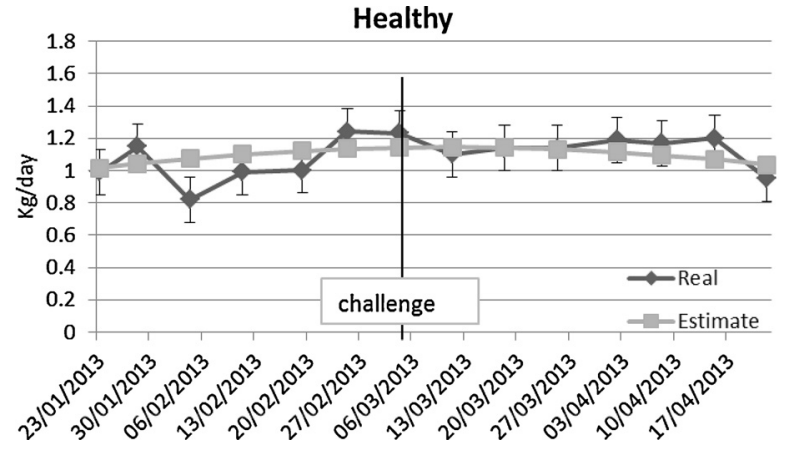

Fig. 1a. Lactation curves of not infected ewes.

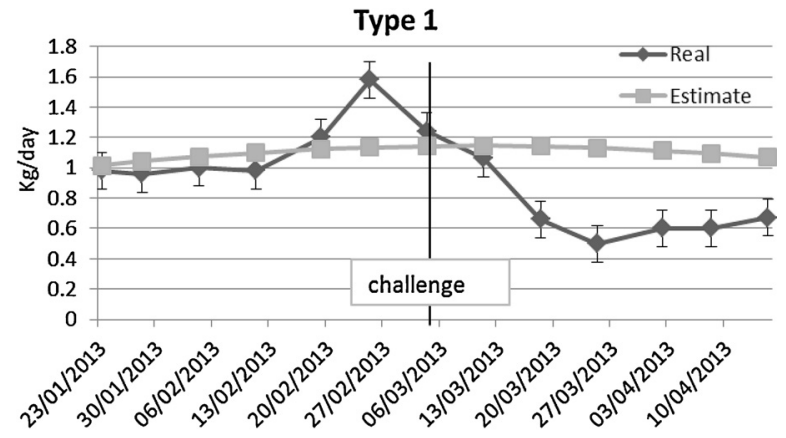

Fig. 1b. Lactation curves of Type 1 infected ewes.

The lactation curves for each type highlighted are reported in Fig. 1(a-d).

Fig. 1a shows the lactation curve of not infected (healthy) ewes from which it can be seen that the estimated curve fitted well with the actual milk data. Fig. 1b shows milk production decreased dramatically following infection; this trend was observed in $36 \%$ of the infected ewes. Fig. 1c shows that milk production was significantly reduced following infection and then increased back to normal levels after about 15-20 days, this trend was observed in $47 \%$ of the infected ewes. In the remaining $17 \%$ of the infected ewes (Fig. 1d) the production of milk does not seem to have been affected by the presence of mycoplasma, probably due to lower daily milk yields. Table 1 shows the effect of Mycoplasma infection on total milk yield for each of the different groups. Among the mycoplasma-infected ewes the greatest losses of milk production occurred

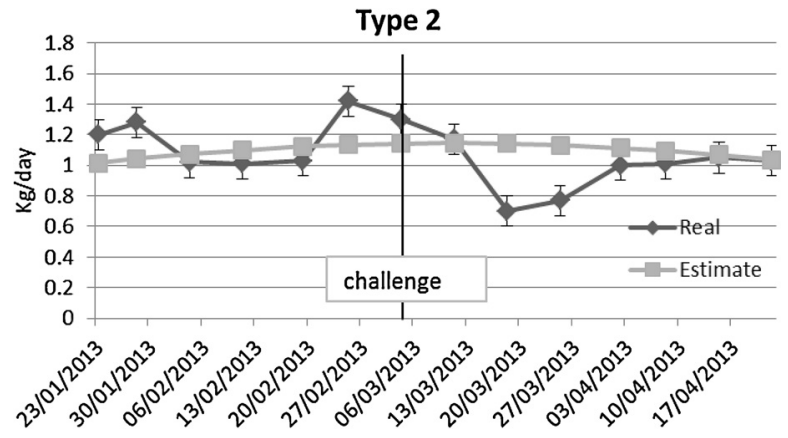

Fig. 1c. Lactation curves of Type 2 infected ewes. 
Table 1

Real and estimated total milk yield respect different type of reaction to Mycoplasma.

\begin{tabular}{llll}
\hline $\begin{array}{l}\text { Mycoplasma reaction } \\
\text { type }\end{array}$ & $\begin{array}{l}\text { Estimated milk yield } \\
x \pm \text { se } \\
(n)\end{array}$ & $\begin{array}{l}\text { Real milk yield } \\
x \pm \text { se } \\
(\mathrm{kg})\end{array}$ & $\begin{array}{l}\text { Difference } \\
\mathrm{kg}(\%)\end{array}$ \\
\hline Type 1 $(13)$ & $95.72 \pm 6.27 \mathrm{a}$ & $79.32 \pm 6.27 \mathrm{~b}$ & $16.4(17.13)$ \\
Type 2 $(17)$ & $96.84 \pm 5.48$ & $94.02 \pm 5.48$ & $2.82(2.91)$ \\
Type 3 $(6)$ & $88.90 \pm 9.23$ & $73.77 \pm 9.23$ & $15.13(17.02)$ \\
Healthy $^{\mathrm{a}}(10)$ & $91.30 \pm 7.15$ & $94.20 \pm 7.15$ & $-2.90(3.18)$ \\
\hline
\end{tabular}

On the row, different letters are significant $P<0.05$.

a Negative for M. agalactiae, STAU and CNS.

in type 1 . The milk production was reduced by $17.13 \%$ which was statistically significant $(P<0.05)$. In contrast, the infected ewes classified as type 2 also had reduced milk production following the challenge but recovered after about 15-20 days, showing a statistically insignificant milk reduction, equal to $2.91 \%$. Compared to the uninfected ewes, the type 3 infected ewes produced 17\% less milk; this does not appear to be due to mycoplasma infection, but probably to the low level of production in this group of ewes. The lower production of infected sheep, on average was approximately $10 \%$, in agreement with data reported by other authors (Gonzalo et al., 2002). Another, this study showed that about $50 \%$ of infected sheep were unable to resume normal milk production 2-3 weeks after infection.

Table 2 shows the effects of M. agalactiae and other mastitic agents on milk yield and composition. The presence of the mastitis agents, CNS and S. aureus, did not statistically influence the morning milk production and its composition; in contrast the presence of mycoplasma, regardless of its concentration in milk, always significantly affected milk yield and its quality. The presence of mycoplasma in milk, regardless of its concentration, provoked significant reductions of milk at the morning milking (708 vs $420 \mathrm{~g} / \mathrm{d}$, $P<0.01 ; 708$ vs $303 \mathrm{~g} / \mathrm{d}, P<0.01)$.

The milk somatic cells count (SCC) increased with the presence of mycoplasmas, although statistically significant differences $(P<0.01)$ were only found between negative animals and those positive with over $10^{3} \mathrm{CFU} / \mathrm{ml}$ of mycoplasma in the milk, while no significant difference emerged between negative and positive animals with less than $10^{3} \mathrm{CFU} / \mathrm{ml}$. No significant differences were found in milk samples where other bacteria were isolated.

Several authors have reported that $M$. agalactiae in ewe milk increases SCC both in bulk milk tank (Gonzalo

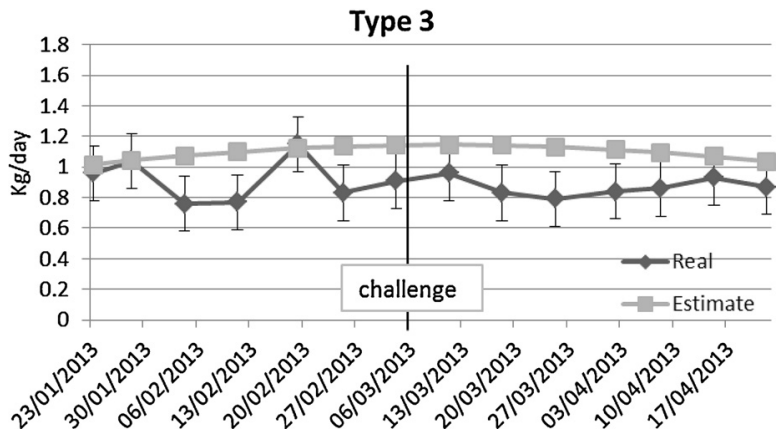

Fig. 1d. Lactation curves of Type 3 infected ewes. et al., 2005) and in individual milk samples in experimentally infected ewes (Bergonier et al., 1996). The significant increase of SCC in milk excreting large amounts of mycoplasma $\left(>10^{3} \mathrm{CFU} / \mathrm{ml}\right.$ ) was due to the fact that the highest elimination of mycoplasma in the milk was observed at the beginning of infection which decreased thereafter, along with the SCC seen also by Bergonier et al. (1996). The lack of significant differences in milk yield and SCC related to the presence of other pathogens (STAU and CNS), also found in other studies (Gonzalo et al., 2002; Leitner et al., 2004), was probably due to the low variability absorbed by this factor in the statistical model employed.

With regard to the milk chemical composition (Table 2 ), the percentages of protein and casein in milk samples of animals with active infections were higher than noninfected ewes while, in contrast, the percentage of lactose in these was higher than infected ewes. No significant differences were found in milk fat percentages amongst the groups; in addition the concentration of mycoplasma did not affect the chemical composition of the milk.

Discordant data about the effects of CA on milk composition are present in the literature: some authors reported significant effects (Burriel, 1997; Leitner et al., 2003) while other authors do not (de la Fe et al., 2009; Fox et al., 2003). The effect of mycoplasma infection on milk protein and casein percentages is probably due to reduced udder functionality, that leads to lower synthesis of casein and protein milk. As regard milk lactose, it is well known that this milk component is positively correlated with milk production (Pulina and Bencini, 2004), so that non-infected ewes, that produced more milk, showed higher percentages of lactose than other ewes.

Mycoplasma also clearly has an adverse effect on the amount of fat and protein produced at morning milking which would result in lower production of cheese.

Table 2 reports the effects on milk yield and milk composition of the interaction between S. aureus and M. agalactiae. When both microorganisms are present at the same time, the effect on milk yield was particularly severe so that milk yield was reduced by over a third (Table 2). Also the percentage of lactose is statistically lower in the milk of infected sheep which reflects the positive correlation between milk yield and lactose percentage. In both cases the variation of milk yield and milk lactose percentage are independent of $M$. agalactiae concentration.

Mycoplasma had negative effects on milk fat and milk protein daily content, probably because the udders of infected ewes presented less functionality and consequently produced less milk fat and milk protein. 


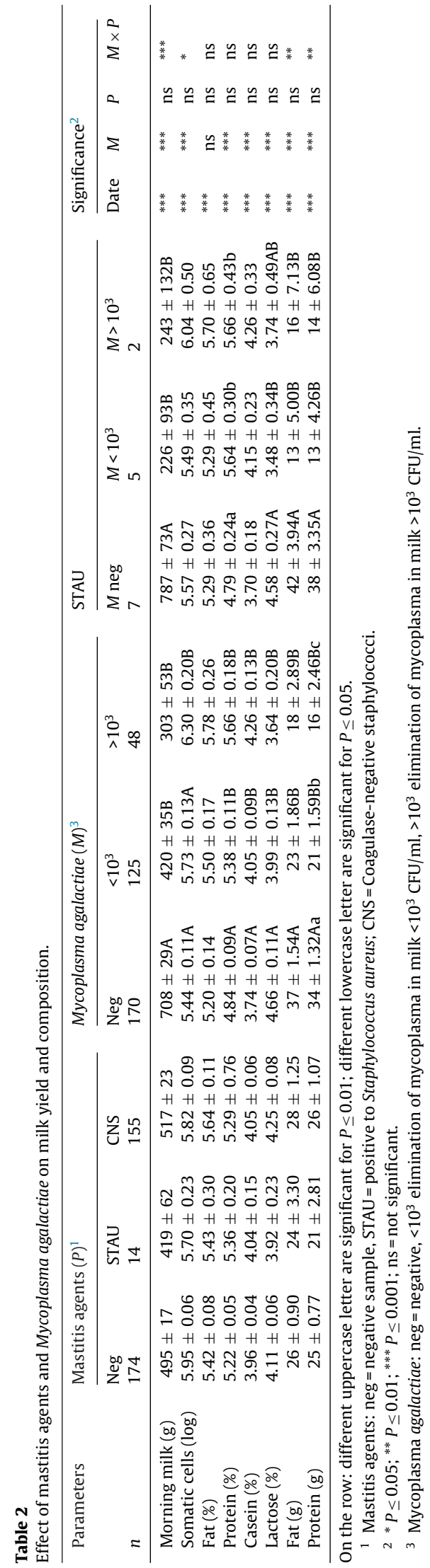

Several studies report that the presence of other contagious mastitis pathogens, as $S$. aureus, is not affected to the presence of mycoplasma, suggesting that the aetiology and transmission of mycoplasma mastitis are different from transmission of other contagious mastitis pathogens (de la Fe et al., 2009; Fox et al., 2003). Our data, here, shows that infection with these two microorganism leads to an increased impact on milk production due.

\section{Conclusions}

Contagious agalactia has always been recognized as a costly disease particularly in dairy ewes but no financial estimates have ever been made in southern Europe. The affected animals showed a reduction in milk production of up to $17 \%$, and a change in its chemical composition, although no correlation was seen as regards to M. agalactiae concentration in milk. The reduction in milk production was especially high when the effect of mycoplasma was exacerbated by a co-infection with Staphyloccus aureus. However, after almost 2 weeks from the beginning of the infection, the majority of ewes excreting $M$. agalactiae in the milk recovered to almost normal lactation levels.

Analysis of milk composition showed a change of chemical parameters which affected quality of cheese yield namely the percentages fat and protein. Nevertheless in the clinically infected group the loss of $17 \%$ of the milk production, to which must be added the low quality of raw milk suitable for dairy production, should represent the minimum which must be added to the costs of veterinary time, treatment and vaccination associated with controlling CA. Running the present experiment under controlled environmental conditions, as was done here, has probably significantly under estimated the severity of the disease.

\section{Conflict of interest}

None declared.

\section{Acknowledgment}

This study was funded by the Ricerca Corrente of the Italian Ministry of Health (RC IZS Si 05/2010 and IZS Si 04/2012).

We are very grateful to $\mathrm{Dr}$ Robin Nicholas of Mycoplasma Laboratory, Animal Health Veterinary Laboratories Agency-Weybridge, UK for his technical supervision.

\section{References}

Agnone, A., La Manna, M., Sireci, G., Puleio, R., Usticano, A., Ozdemir, U., Chiaracane, V., Dieli, F., Di Marco, V., Loria, G.R., 2013. A comparison of the efficacy of commercial and experimental vaccines for contagious agalactia in sheep. Small Rumin. Res. 112, 230-234.

Bergonier, D., Gracianette, G., Andrieu, C., Berthelot, X., 1996. Reproduction expérimentale de l'agalactie contagieuse de la brebis: évolution des comptages cellulaires individuels durant trois lactations consécutives. In: Rubino, R. (Ed.), Somatic Cells and Milk of Small Ruminants. EAAP Publ. No. 77. Wageningen Pers Publ., Wageningen, The Netherlands, pp. 93-97.

Bergonier, D., Berthelot, X., 2003. New advances in epizootiology and control of ewe mastitis. Livest. Prod. Sci. 79, 1-16. 
Burriel, A.R., 1997. Dynamics of intra-mammary infection in sheep caused by coagulase-negative staphylococci and its influence on udder tissue and milk composition. Vet. Rec. 140, 419-423.

Cappio-Borlino, A., Pulina, G., Rossi, G., 1995. A non-linear modification of Wood's equation fitted to lactation curves of Sardinian dairy ewes. Small Rumin. Res. 18, 75-79.

Cappio-Borlino, A., Portolano, B., Todaro, M., Macciotta, N.P.P., Giaccone, P., Pulina, G., 1997. Lactation curves of Valle del Belice dairy ewes for yields of milk, fat, and protein estimated with test day models. J. Dairy Sci. 80, 3023-3029.

CICPE, 1992. Règlement international pour le contrôle laitier ovin. CICPE, Roma.

Corrales, J.C., Sánchez, A., Luengo, C., Poveda, J.B., Contreras, A., 2004. Effect of clinical contagious agalactia on the bulk tank milk somatic cell count in Murciano Granadina goat herds. J. Dairy Sci. 87, 3165-3171.

Contreras, A., Miranda, R.E., Sánchez, A., De la Fe, C., Sierra, D., Luengo, C., Corrales, J.C., 2008. Presence of Mycoplasma species and somatic cell counts in bulk-tank goat milk. Small Rumin. Res. 75, 247-251.

de la Fe, C., Sánchez, A., Gutierrez, A., Contreras, A., Carlos Corrales, J. Assunçao, P., Poveda, C., Poveda, J.B., 2009. Effects on goat milk quality of the presence of Mycoplasma spp. in herds without symptoms of contagious agalactia. J. Dairy Res. 76, 20-23.

Farina, R., Contini, A., Pascucci, S., 2002. Mycoplasma, Ureaplasma e Acheloplasma. In: Farina, R., Scatozza, F. (Eds.), Trattato di Malattie Infettive degli Animali. , 2 Ed. UTET, Torino, Italy, pp. 398-404.

FIL-IDF Bulletin 132:1981, 1981. Laboratory methods for use in mastitis work., pp. 19-27.

Foglini, A., 1997. L’Agalassia contagiosa e le regioni ovine (Contagiosus agalactiae and sheep areas). Caseus 1,11-14

Fox, L.K., Hancock, D.D., Mickelson, A., Britten, A., Kaaden, O.R., 2003. Bulk tank milk analysis: factors associated with appearance of Mycoplasma sp. in milk. J. Vet. Med. B 50, 235-240.

Guarda, F., Mandelli, G., 1989. Trattato di Anatomia Patologia Veterinaria, 2 Ed. UTET, Torino, Italy, pp. 68.

Gonzalo, C., Ariznabarreta, A., Carriedo, J.A., San Primitivo, F., 2002. Mammary pathogens and their relationship with somatic cell count and milk yield losses in dairy ewes. J. Dairy Sci. 85, 1460-1467.

Gonzalo, C., Carriedo, J.A., Blanco, M.A., Beneitez, E., Juarez, M.T., De La Fuente, L.F., Primitivo, F.S., 2005. Factors of variation influencing bulktank somatic cell count in dairy sheep. J. Dairy Sci. 88, 969-974.

Harmon, R.J., 1994. Physiology of mastitis and factors affecting somatic cell counts. J. Dairy Sci. 77, 2103-2112.

Leitner, G., Chaffer, M., Caraso, Y., Ezra, E., Kababea, D., Winkler, M., Glickmana, A., Saran, A., 2003. Udder infection and milk somatic cell count,
NAGase activity and milk composition-fat, protein and lactose-in Israeli-Assaf and Awassi sheep. Small Rumin. Res. 49, 157-164.

Leitner, G., Chaffer, M., Shamay, A., Shapiro, F., Merin, U., Ezra, E., Saran, A., Silanikove, N., 2004. Changes in milk composition as affected by subclinical mastitis in sheep. J. Dairy Sci. 87, 46-52.

Miles, R., Nicholas, R.A.J., 1998. Humana Books. Totowa, USA, pp. 37-44.

Marcato, P.S., 1992. Mastite da Micoplasmi. In: Marcato, P.S. (Ed.), Patologia Mammaria Animale. , 1 Ed. Edagricole, Bologna, Italy, pp. 34-50.

McAuliffe, L., Ellis, R., Ayling, R.D., Nicholas, R.A.J., 2003. Differentiation of Mycoplasma species by $16 \mathrm{~S}$ ribosomal DNA PCR and denaturing gradient gel electrophoresis fingerprint. J. Clin. Microbiol. 41, 4844-4847.

Meynell, G.G., Meynell, E., 1970. Bacterial growth. In: Meynell, G.G., Meynell, E. (Eds.), Theory and Practice in Experimental Bacteriology. Cambridge University Press/Mosby-Year Book Europe Limited, UK/London, pp. 1-9.

Nicholas, R.A.J., Baker, S., 1998. Recovery of Mycoplasma from animals. In Miles, R.J., Nicholas, R.A.J. (Eds.), Mycoplasma Protocols, Methods in Molecular Biology, 104. Humana Books Press, Totowa, NJ, pp. 37-43.

Nicholas, R.A.J., Ayling, R.D., Loria, G.R., 2008. Ovine mycoplasmal infections. Small Rumin. Res. 76, 92-98.

Nicholas, R.A.J., Loria, G.R., 2014. Contagious agalactia: the shepherd's nightmare. Vet. J. 198, 5-6.

Poveda, J.B., Nicholas, R.A.J., 1998. Serological identification of Mycoplasmas by growth and metabolic inhibition tests. In: Miles, R.J., Nicholas, R.A.J.(Eds.), Mycoplasma Protocols, Methods in Molecular Biology, vol. 104. Humana Books Press, Totowa, NJ, pp. 105-111.

Pulina, G., Bencini, R., 2004. Dairy Sheep Nutrition. CABI Publ., Wallingford, UK, pp. 222.

Ramirez, A.S., Garcia, M., Diaz-Bertrana, L., Fernandez, A., Poveda, J.B. 2001. Goat and sheep abortions associated with Mycoplasma agalactiae in Northern Spain. In: Poveda, J.B., Fernandez, A., Frey, J., Johansson, K.-E. (Eds.), Mycoplasmas of Ruminants: Pathogenicity, Diagnostics, Epidemiology and Molecular Genetics, vol. 5. Office for Official Publication of the European Communities, Luxembourg, pp. $122-125$.

Solsona, M., Lambert, M., Poumarat, F., 1996. Genomic, protein homogeneity and antigenic variability of Mycoplasma agalactiae. Vet. Microbiol. 50, 45-58.

Tola, S., Manunta, D., Rocca, S., Rocchigiani, A.M., Idini, G., Angioi, A., Leori, G., 1999. Experimental vaccination of against Mycoplasma agalactiae using different inactivated vaccine. Vaccine 17, 2764-2768.

Wood, P.D.P., 1967. Algebraic model of the lactation curve in cattle. Nature 216, 164-165. 